\title{
Communication \\ A Framework for Financing Post-Registration Variety Testing System: A Case Study from Poland
}

\author{
Gniewko Niedbała ${ }^{1, *(\mathbb{D})}$, Anna Tratwal ${ }^{2}$, Magdalena Piekutowska ${ }^{3}\left(\mathbb{D}\right.$, Tomasz Wojciechowski ${ }^{1}$ (D) \\ and Jarosław Uglis $4, * \mathbb{D}$
}

1 Department of Biosystems Engineering, Faculty of Environmental and Mechanical Engineering, Poznań University of Life Sciences, Wojska Polskiego 50, 60-627 Poznan, Poland; tomasz.wojciechowski@up.poznan.pl

2 Department of Monitoring and Signalling of Agrophages, Institute of Plant Protection-National Research Institute, Władysława Węgorka 20, 60-318 Poznan, Poland; a.tratwal@iorpib.poznan.pl

3 Department of Geoecology and Geoinformation, Institute of Biology and Earth Sciences, Pomeranian University in Słupsk, Partyzantów 27, 76-200 Slupsk, Poland; magdalena.piekutowska@apsl.edu.pl

4 Department of Law and Enterprise Management in Agribusiness, Faculty of Economics, Poznań University of Life Sciences, Wojska Polskiego 28, 60-637 Poznan, Poland

* Correspondence: gniewko.niedbala@up.poznan.pl (G.N.); jaroslaw.uglis@up.poznan.pl (J.U.)

check for updates

Citation: Niedbała, G.; Tratwal, A.; Piekutowska, M.; Wojciechowski, T.; Uglis, J. A Framework for Financing Post-Registration Variety Testing System: A Case Study from Poland. Agronomy 2022, 12, 325. https:// doi.org/10.3390/agronomy12020325

Academic Editors: Djamilia Skripnuk, Gulnara Romashkina and

Pasquale Tripodi

Received: 30 December 2021

Accepted: 24 January 2022

Published: 26 January 2022

Publisher's Note: MDPI stays neutral with regard to jurisdictional claims in published maps and institutional affiliations.

Copyright: (C) 2022 by the authors. Licensee MDPI, Basel, Switzerland. This article is an open access article distributed under the terms and conditions of the Creative Commons Attribution (CC BY) license (https:// creativecommons.org/licenses/by/ $4.0 /)$.

\begin{abstract}
Agriculture is essential to ensuring food security and prosperity around the world. The importance of cultivating agricultural plant species cannot be overestimated. One of the key challenges faced by modern food producers is to increase efficiency while ensuring sustainability and improving resilience to unfavorable environmental conditions brought about by ongoing climate change. To meet these challenges, it is vital to continue breeding work and to select plant varieties best adapted to local farming conditions. Undoubtedly, future yield increases will only be achievable by way of genetic improvement. In turn, crop-variety recommendations should rely on the results of properly designed post-registration variety testing (PRVT, in polish PDO), followed up by specific variety recommendations for growers. In this article, we attempt to fill a gap in the international literature regarding post-registration variety testing. We present PRVT as a unique scheme that is key to selecting agricultural plant varieties recommended for cultivation, with due account taken of Poland's specific farming conditions. Every year, over 1000 field cultivar tests are carried out as part of PRVT. The results of these tests constitute reliable, objective source material for farmers and help them make choices regarding the most valuable varieties for cultivation that are also best adapted to local farming conditions. Among the financial benefits of selecting the right crop varieties for agriculture are lower cultivation costs, including reduced fertilizer and pesticide spending, and higher income generated by larger yields.
\end{abstract}

Keywords: post-registration variety testing; PRVT; PDO; sources of financing; variety evaluation; plant breeding

\section{Introduction}

Whether during or post-registration, plant variety testing plays a crucial role in the application of advances in biological science in farming practice. Variety testing is also instrumental in achieving sustainable development goals at national and global levels. While the results of variety tests conducted in various agrotechnical systems ranging from conventional to simplified help to protect soil and water, they also support agricultural adaptation to climate change. Therefore, tests play a key role in combatting climate change and environmental degradation, as explicitly stated in the objectives of the European Green Deal and Farm-to-Fork programs. Improvements of crop-variety traits, especially those associated with plant resistance to disease, are viewed as potentially effective in light of 
successive revocations of plant-protection product approvals for selected plant species, as well as the prospect of a $50 \%$ reduction in the number of approved products. In the field of nitrogen fertilization, the results of post-registration variety testing can be helpful in achieving the Green Deal objective of reducing the environmental and climate footprint of the food system. The importance of post-registration testing in environment-friendly and organic farming systems is also increasing. Organic crop yields are as much as $35 \%$ lower than yields of conventional cultivation systems. This shows that the key to increasing the share of environment-friendly and organic farms in Europe by acreage, which is currently below 3\% [1], is to raise crop yields by breeding and selecting superior plant varieties to better fit the soil and climate conditions found in specific regions [2]. The emphasis that European and national policies place on digitization designed to advance ecological transformation and sustainability also affects the testing industry, which is undergoing a digital revolution, just as any other sector of the economy.

The aim of this article is to show the importance of post-registration variety testing for selecting the agricultural plant varieties to be recommended for growing, with due account taken of local farming conditions and profitability, as well as sources of funding. Additionally, the authors attempt to estimate the financial benefits of selecting the right plant varieties for cultivation.

\subsection{Theoretical Background}

\subsubsection{The European Union's Cultivated Plant Variety Registration Procedure}

In the European Union, varieties are listed in a two-stage procedure, while the marketing of the seeds of crop varieties is regulated by as many as twelve basic pieces of legislation [3]. These official documents only allow the sale of seeds when a given variety is entered in the National Variety List (kept separately for each member state). On the basis of the National Lists of EU member states, the European Commission compiles the Common Catalogue of Varieties of Agricultural Plant Species (CCA) and the Common Catalogue of Varieties of Vegetable Species (CCV). The varieties listed in the above two universal catalogues are freely marketable throughout the union [4].

To be included in a member-state list, a variety must undergo official tests of distinctiveness, uniformity, and stability (DUS); additionally, as is the case for most plant species, a variety must be tested for its value for cultivation and use (VCU) [3]. DUS tests are conducted based on guidelines developed by the Community Plant Variety Office (CPVO) and the International Union for the Protection of New Varieties of Plants (UPOV) [5]. In Poland, basic vegetable and fruit plant varieties can only be admitted to the National List on the basis of DUS tests. For the most important species of such plants, varieties are not tested for value for cultivation and use until they have been included in the National List. For agricultural plant species, a variety's admission to the National List is conditional upon it passing DUS tests and being shown to have satisfactory value for cultivation and use (VCU). An entity seeking to have a variety included in the National List applies accordingly with the Research Center for Cultivar Testing (COBORU), at which point the material they submit is tested in subsequent test cycles. The variety is eligible for listing, provided it is distinct, uniform, and stable; has a satisfactory cultivation and use value (with some exceptions); is retained; and has a name that complies with the applicable requirements. Fruit plant species are included in the National List for 30 years, while all other species of cultivated plants are listed for 10 years [4]. Needless to say, this time limit may be extended.

Successful registration of a variety is reflected in what happens to the tested genotypes at a later time. For the seed sector to flourish, active cooperation of farmers, local governments, breeders, traders, and other stakeholders is essential. In most EU countries, it is breeders and researchers who select varieties for various tests and subsequently evaluate test results. Very few organizations actively involve farmers in variety selection and evaluation. For example, in the 2017-2018 season in Italy, VCU tests on organic varieties were carried out by the Italian Farmers' Seed Network (RSR) on about 40 farms [6]. In Poland, such tests were conducted at six sites belonging to the Institute of Cultivation, Fertilization 
and Soil Science of the National Research Institute in Puławy, as well as two sites on farms. During the same period in Germany, organic varieties were tested exclusively on farms. The differences in the share of new genotype tests in which specific stakeholder groups are involved depend not only on the organization of agriculture in each country but also, and primarily so, on who funds such activities. For instance, most of the European institutions responsible for testing organic varieties in the EU rely on public funding. In Switzerland and the UK, financing comes from the users, who pay fees that are tied to their yields, among other factors. In other countries, test costs are either funded by projects in equal proportions (Hungary, Italy, Latvia) or paid for out of farmer membership fees (Denmark).

\subsubsection{Significance of DUS and VCU Tests}

Distinctiveness, uniformity, and stability tests (DUS) show whether a newly developed genotype differs from other varieties listed for a given species. The tests reveal whether all the traits that define distinctiveness are expressed uniformly and whether such traits change from one generation to the next. This helps verify the distinctiveness, uniformity, and stability of the tested variety [7]. DUS tests are conducted for two main purposes. One is to allow the new varieties that pass the tests to be included in the National List and therefore marketed. The list is an official register of agricultural, vegetable, and fruit plant varieties, the reproductive material of which may be produced and distributed in Poland and elsewhere in the EU.

In the case of agricultural and vegetable varieties, the material intended for marketing in the EU must be included in either of the common catalogues (the CCA or the CCV). DUS tests are also a way to grant varieties legal protection in what amounts to a unique form of ownership. In effect, only breeders holding exclusive rights to a specific variety are allowed to produce, reproduce, sell, and/or store the seeds of the protected variety. In Poland, exclusive rights to plant varieties are governed by numerous provisions of national and community law [8-11]. DUS tests are carried out in the field or in greenhouses during two growing seasons. The tests are conducted in keeping with specific guidelines made uniform by the Research Center for Cultivar Testing (COBORU). As a result, all EU countries conduct their tests in the same manner and follow the same procedure to describe their tested varieties. This approach makes it possible to use and compare test results across multiple countries. The expectation is that the tests will reveal numerous (mainly morphological) traits of the candidate and similar varieties. Any tests that have been carried out in uncommon conditions that impede comparisons are extended for another year. Trait comparisons between varieties facilitate the drawing up of final test reports that contain botanical descriptions of the concerned cultivars [4].

Tests for the cultivation and use value of varieties are carried out to evaluate their agronomic characteristics, their resistance to diseases and pests, the timing of their subsequent growth and phenological phases, their resistance to factors in the physical environment, and the quality characteristics of the main crop [4,12]. It is difficult to universally define the cultivation and use value of varieties. According to article 8.1 of the law of 9 November 2013 on seed production, "a variety with a satisfactory cultivation and use value is one that, compared to varieties included in the National List, displays—either throughout Poland or exclusively in some of its regions-properties that raise their value for the cultivation, processing and use of plants or any products derived therefrom; such a variety may have a single property that is inferior to its equivalent found in varieties included in the National List, provided that such a property is offset by other superior properties" [13]. Throughout Poland, for each plant species/category, VCU tests are conducted by standard methods developed and adopted by COBORU. VCU test results are published regularly in a variety of descriptive lists.

\subsubsection{A Brief Outline of the Post-Registration Variety Testing Scheme}

Tests concerning the cultivation and use value of the varieties of selected agricultural plant species may be continued in post-registration variety testing (PRVT; in Polish, PDO). 
In this scheme, tests provide essential source information on many variety traits manifested in specific environmental conditions. Such tests are intended to provide direct support to agricultural practitioners. They are conducted at over one hundred sites. In addition to being helpful for evaluation of the cultivation and use value of varieties, PRVT test results are used to draw up lists of varieties recommended (LVR). Such lists contain basic information on the characteristics of varieties that make up their cultivation and use value and, the analysis and comparison of which points to varieties to be recommended for cultivation in each region (voivodeship) of Poland [4,14,15]. COBORU [4] coordinates the system at the central level.

Poland's post-registration variety-testing system was first deployed in 1998. It took several years to extend the system to cover the entire country. Table 1 presents a timeline of the rollout of the PRVT scheme and the dissemination of its findings in agricultural practice.

Table 1. Timeline of PRVT rollout and dissemination of results in Poland.

\begin{tabular}{|c|c|}
\hline Year & Steps Taken \\
\hline 1997 & The design of Polish post-registration variety testing (PRVT) and variety recommendations is proposed. \\
\hline 1998 & $\begin{array}{c}\text { Precepts and schedule are agreed upon for the design and rollout of PRVT scheme. A task force is appointed to } \\
\text { establish PRVT. }\end{array}$ \\
\hline 1998 & First variety trials are set up as part of PRVT. \\
\hline 1999 & A PRVT task force is established in every region of Poland. \\
\hline 2000 & Legislation is adopted to govern the operation of the PRVT scheme in Poland. \\
\hline 2003 & Regional PRVT coordination stations, regional PRVT teams, and a national PRVT coordination team are appointed. \\
\hline 2004 & $\begin{array}{c}\text { The National PRVT Coordination Team adopts principles for creating lists of varieties recommended for cultivation } \\
\text { in every region (LVR), as well as rules and procedures for PRVT of varieties from the Common Catalogue of } \\
\text { Varieties of Agricultural Plants (CCA). }\end{array}$ \\
\hline 2004-2005 & $\begin{array}{l}\text { In every region, COBORU concludes agreements with its statutory partners (marshals' offices and agricultural } \\
\text { chambers) regarding cooperation within the PRVT scheme. }\end{array}$ \\
\hline 2011 & $\begin{array}{c}\text { The post-registration variety-testing (PRVT) scheme is transformed into post-registration variety and agricultural } \\
\text { testing (PRVAT). }\end{array}$ \\
\hline 2011-2012 & $\begin{array}{l}\text { In every region, agreements between COBORU and its statutory partners (marshals' offices and agricultural } \\
\text { chambers) are renewed to cover cooperation within PRVAT. }\end{array}$ \\
\hline 2015 & The former name of the scheme, i.e., post-registration variety testing (PRVT), is restored. \\
\hline 2018 \& the following years & The Polish scheme of PRVT and variety recommendations is strengthened and consolidated. \\
\hline 2021 & $\begin{array}{l}\text { A list of varieties recommended for cultivation in } 2021 \text { is disseminated among all farmers through the Agricultural } \\
\text { Social Insurance Fund (KRUS). }\end{array}$ \\
\hline
\end{tabular}

In 2000, the scheme was legally adopted by amendments to the Seed Act [16]. All organizational PRVT-related details were laid down in Executive Order 11 of the Minister of Agriculture and Rural Development of 11 June 2002, establishing the charter of the Research Center for Cultivar Testing [17]. Currently, these provisions are found in the amended regulation of 2010 [18]. The concept of developing the PRVT scheme envisioned establishing a multibody, interinstitutional test system modeled on pan-European solutions. The organizational structure of the Polish PRVT scheme is shown in Figure 1. The program was intended to involve bodies and organizations concerned with variety testing and adoption of biological accomplishments on Polish farms. Such bodies and organizations include local governments, farmers' organizations, national government bodies, advisory services, breeding/seed companies, research institutes, and processing-industry companies. This innovative system was inspired by the need to reliably test varieties and upscale testing to cover the whole country following a sharp decline in test numbers in the late 1990s.

The PRVT scheme involves variety and agrotechnical-variety tests at several dozen observation points, with full use of available test resources, including test stations, plant breeding stations, agricultural advisory centers, universities, and farms [4].

The Polish PRVT scheme is overseen and managed by a two-tier structure. The national PRVT coordination team runs the PRVT from a central level. It serves in an opinion-making and advisory capacity to the COBORU head. Members of this team offer opinions on the procedures and rules applied in running the PRVT, develop a common system of presentation for test results, and manage the procedures and methods used in preparation of the list of varieties recommended (LVR) for cultivation in each voivodeship. At the regional level, the PRVT scheme is managed by the regional/district PRVT coordinating 
stations and district PRVT teams. The coordinating stations are responsible for managing and technically supervising PRVT operations in respective regions, as well as preparing the technical and financial aspects of trial plans. The coordinating stations are supported by regional PRVT teams, the members of which are field experts from various institutions and organizations who deal with seeds in their daily practice. The teams also contribute to the drafting of "lists of varieties recommended for cultivation in voivodeships" and to selection of varieties to be tested during specific growing seasons $[4,19]$.

National PRVT Coordinator

COBORU Director General

Units directly responsible for PRVT

management
Experimental Station for Cultivar

Testing and other test units in the region
Variety Testing Research Institute in Słupia Wielka
Consultative bodies

National PRVAT Coordination Council
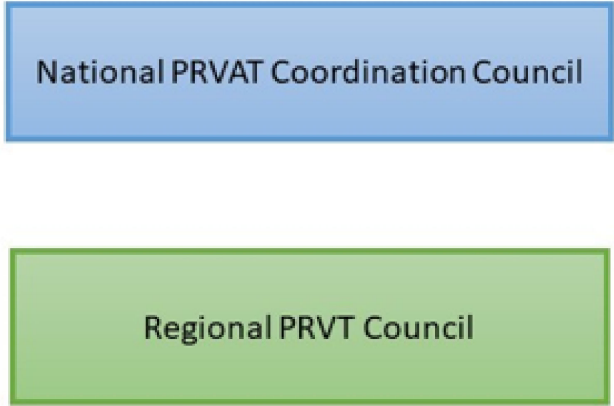

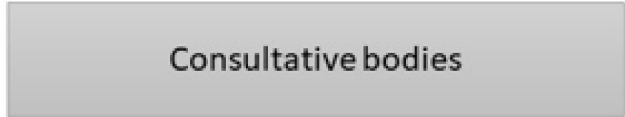

\section{(1)}

Figure 1. Organization of PRVT testing and variety recommendation system in Poland.

The presumption made during the development of the PRVT scheme was that it would ultimately be financed primarily by entities particularly concerned with monitoring variety performance in specific habitats and specific agrotechnical conditions. These include producers' associations, agricultural chambers, processing plants, local governments, trade and advisory companies, and farmers. Over its more than two decades in operation, most of the PRVT scheme's financing has come from the state. The issues encountered in deploying funding in accordance with the original precepts are most likely the result of the continuing fragmentation of farms and of the fact that only a small percentage of industry producer groups show interest in supporting the multidimensional testing of varieties [19].

The synergies generated by cooperating research institutes and central and local authorities help agricultural producers select varieties best suited for the local conditions found on their farm [5]. The unique nature of the PRVT scheme in the EU lies primarily in providing regular, reliable updates on the value of varieties tested country-wide in a range of habitats and climatic conditions. In the current testing approach, multiple factors are considered in evaluating varieties. This has led to, for example, the development of two levels of agrotechnics. This is of great importance for crop species that require varying levels of spending. The PRVT scheme performs a regulatory function of controlling the transfers of new, domestic, and foreign varieties to agricultural practice. PRVT test results lay the groundwork for advanced scientific research in agriculture, including research on the stability and quality of spring wheat grain yields [20], genotype-environment interactions [21], the usefulness of statistical science for studies on adaptations of varieties to the environment [22], and crop yield forecasting [23]. PRVT test results are accessible to the general public, as they are released annually in national and regional publication series [4]. The above information about the PRVT system confirms the statement that it is 
an innovative agricultural experimentation system on a European scale. The results of these experiments are often used in many scientific publications and in agricultural practice. At present, there are no available literature reports indicating the functioning of similar systems in other EU countries. One of the relatively few research project describing VCU systems in European countries in comparison to the Australian system is a paper by Smith et al. [24], who discussed the UK variety testing system, its structure, and its compatibility with VCU systems in EU countries such as Germany or France. However, there is no detailed information available about these system or systems in other EU countries.

\section{Materials and Methods}

For over two decades, Poland has been running a scheme of post-registration variety testing (PRVT) and variety recommendations, providing farmers and other stakeholders with information tailored to their geographies. In this article, we examine the breakdown of the system's financing sources and the rate and course of its changes between 2010 and 2020. Additionally, we outline the main precepts underlying the operation of this unique system that is geared towards satisfying the needs of agricultural practice. The PRVT scheme is also an example of aligning variety testing with sustainable agriculture concepts.

Two research methods, i.e., secondary data analysis and systematic literature review, were used in writing this article [25-27]. The authors applied the fundamental principle of empirical research, which calls for the use of multiple mutually contradictory research methods. This approach reduces the drawbacks of each individual methodology in order to produce more objective findings.

A literature review method is useful when the aim of the paper is to show an overview of a particular issue or research problem. A systematic literature review, on the other hand, is more comprehensive than a literature review because it includes both published and unpublished literature, such as unreleased studies, reports, dissertations, conference papers and abstracts, government studies, etc. Unpublished literature is an essential part of a systematic review and adds value to the review. Typically, this type of literature review is carried out to assess the state of knowledge on a given topic, as it provides an in-depth and detailed review of the existing literature on the subject $[27,28]$.

Today's empirical research increasingly relies on secondary data and materials collected by other researchers, as well as official documents held by various institutions that have carried out similar research, even if for different purposes $[26,29,30]$. There are three main advantages of using empirical data from secondary sources for the purposes of analysis. First, such data provide access to more diverse data sets that offer more extensive insights than those achievable on the basis of primary data alone derived from a single, short-term study. Second, researchers may combine data from secondary sources with their own data derived from observations, interviews, etc. Third, there is a financial advantage, as primary research is an expensive venture, and using existing data can provide substantial cost savings when compared to exclusive reliance on one's own empirical research [31]. The above considerations prompted the authors to avail themselves of secondary materials. Such materials include official reports from the rollout of the post-registration varietytesting scheme in Poland. The data collected for analysis comprised eleven reports from 2010 to 2020 [32-42].

Use was also made of participant observations carried out during the national onthe-job internship held as part of the Best by Nature! Integrated Development Program of Poznan University of Life Sciences carried out at the variety evaluation test station in Słupia Wielka, as well as a free interview [26,43] with the founder and long-term coordinator of the PRVT scheme, professor Edward S. Gacek, who headed the Research Center for Cultivar Testing between 1996 and 2021.

Three data-presentation methods were used to characterize the examined phenomena: tabular, graphical, and descriptive. The elements of descriptive statistics (mean, median, average rate of change), as well as the equation of the trend line and R-square value, were 
used for statistical description of the research results. Microsoft Excel 365 was used to calculate, process, and present the results of data analysis.

In the course of the research, the authors collected highly reliable empirical material for further study. In order to compare their data with those derived from other studies, all financial figures were converted from the Polish zloty to the euro. To eliminate the effect of euro exchange-rate fluctuations on the analyses, the authors applied the mean euro exchange rate of the National Bank of Poland for the 2010-2020 period ( $€ 1=$ PLN 4.2640).

\section{Results}

\subsection{Types and Locations of PRVT Tests}

The variety tests carried out in the PRVT scheme are designed to serve the specific needs of agricultural practice. The main benefits of the scheme are to:

- provide regular access to reliable information on the value of plant varieties in various regions of the country in a range of growing conditions;

- $\quad$ help farmers select the most valuable varieties adapted to local farming conditions for the purposes of cultivation;

- $\quad$ enable agricultural practitioners to make effective use of advances in biological science.

To take advantage of the above benefits, a wide range of entities are actively involved in PRVT testing. Post-registration variety tests are conducted throughout Poland. The distribution of testing sites offers the assurance that all local farming conditions are duly considered. During the period in question, PRVT tests were conducted by 103 entities in 2010 and 99 in 2020. The main organizations involved in testing are the COBORU Research Centers for Cultivar Testing (48), plant breeding organizations (21), agricultural advisory centers (10), and other organizations (20).

The number of variety test programs conducted as part of the PRVT scheme varies by crop species and region. This is due to the significance of the cultivation and use value of a given plant species and the interest in variety-related issues reported by local farming communities. Another vital factor is the source of test financing, which includes contributions from local governments and farmers' organizations.

The number of tests conducted has steadily grown. For instance, 216 tests were carried out in the first year after the launch of the PRVT scheme, followed by close to a thousand (958) in 2010 and 1005 in 2020. The record year was 2016, with a total of 1046 tests completed (see Figure 2).

A breakdown of financing by source shows that the vast majority of funding came from sources other than the state budget $(54.6 \%)$. Funds received from the state and specifically from the Ministry of Agriculture and Rural Development were used to finance an average of $45.4 \%$ of testing expenditures.

As the number of tests climbed, so did the number of agricultural plant species and varieties covered by PRVT procedures. In 2010, tests were extended to 23 plant species and 577 varieties. In 2020, a total of 662 varieties from 26 crop species were tested. The majority of such varieties came from the National List and from the EU's CCA and CCV catalogues.

All post-registration tests of agricultural plant species follow standard methodologies, which are regularly assessed and either updated or replaced with new versions, as needed.

As mentioned above, the scope of PRVT studies (the number of tests and the geographic distribution of test locations) varies from region to region. The voivodeships in which the most post-registration tests are conducted are Wielkopolskie (97), Dolnoślaskie (92), and Kujawsko-Pomorskie (72), with the fewest post-registration tests conducted in the Lubuskie (37), Świętokrzyskie (42), and Warmińsko-Mazurskie (45) voivodeships. To better illustrate PRVT test distributions, use was made of the ratio of total arable land hectares per voivodeship to the number of PRVT test locations. Figure 3 shows the geographic distribution of PRVT testing. 


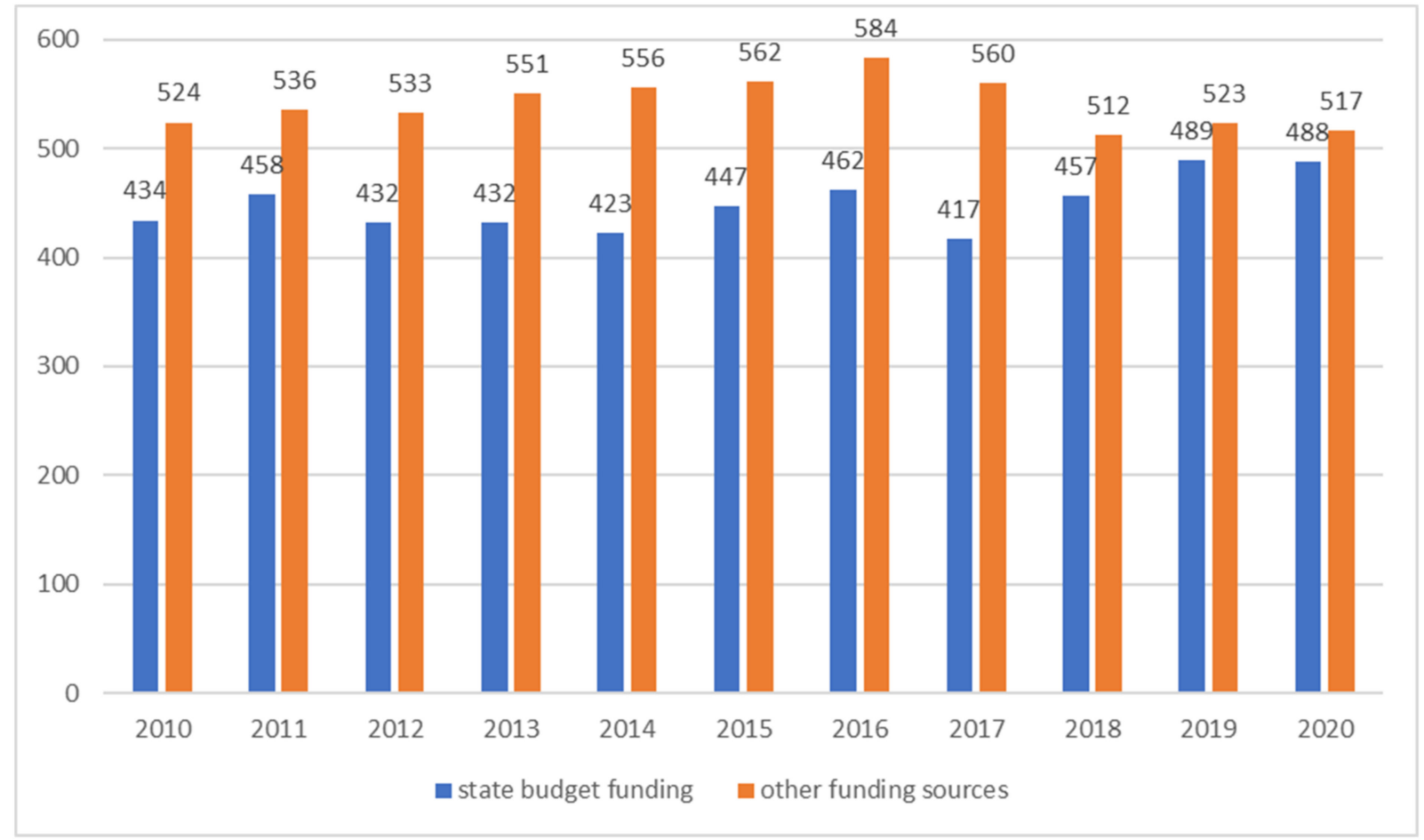

Figure 2. Number of PRVT tests conducted, 2010-2020.

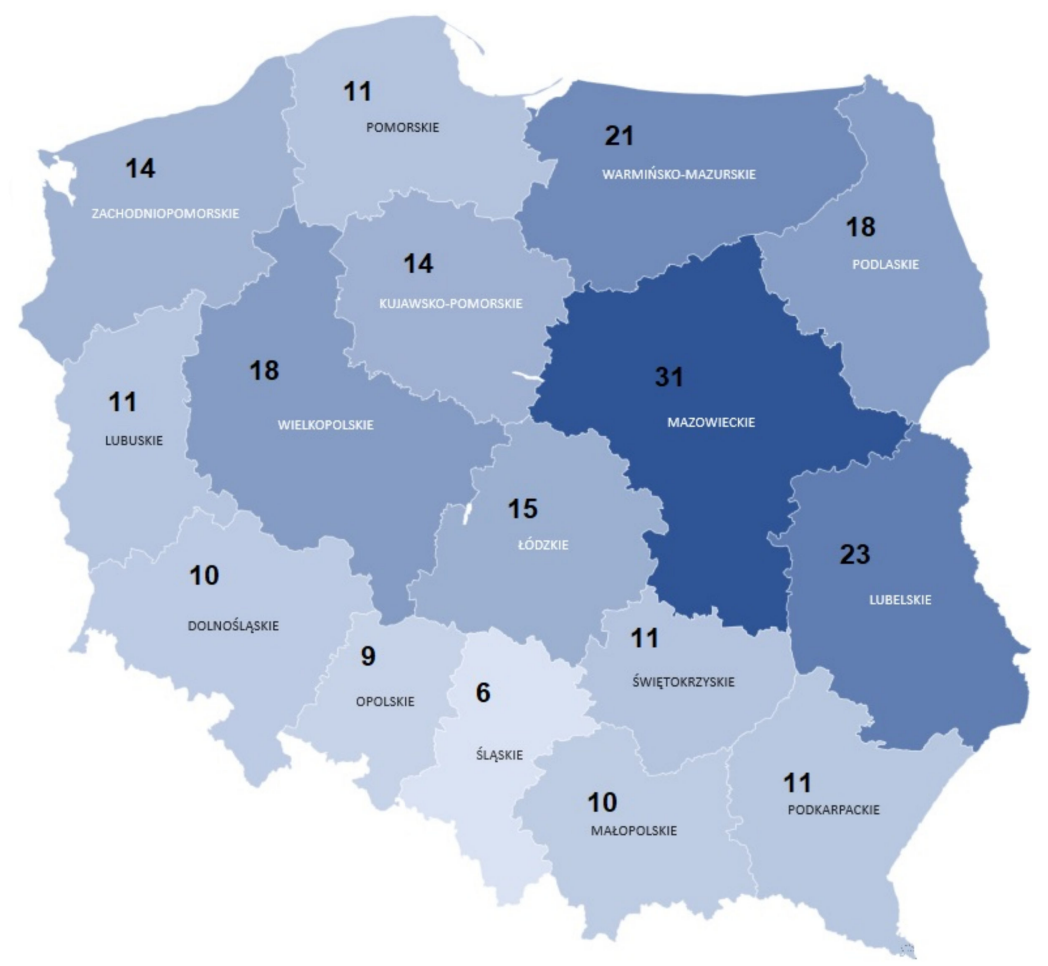

Figure 3. Distribution of PRVT test locations in 2020 (in thousands of hectares).

Based on PRVT test distribution, the Śląskie, Opolskie, Małopolskie, and Dolnośląskie voivodeships were found to have the best coverage, with 6000 to 10,000 hectares of agricultural land per PRVT test location.

PRVT tests are used to create a list of varieties recommended for cultivation in each voivodeship. This list contains recommended crop varieties, the year of registration, yields in each testing year, and other important characteristics, such as the weight of 1000 grains, 
seed-production performance, and resistance to common fungal diseases. The LVR is of great value, mainly for agricultural practitioners (farmers, consultants), because it provides information on the varieties best suited to specific regions. The complete LVR is available in the "PRVT Variety Recommendation" tab on the website of the COBORU [44]. In addition, COBORU leaflets and other printed materials containing descriptive lists of agricultural plant varieties are disseminated among farmers.

\subsection{Financing of PRVT Activities}

The importance of post-registration testing of crop varieties cannot be overestimated. Choosing the right plants for cultivation is central to ensuring food security and a key success factor in farming. To achieve such success, it is vital to secure reliable information on crop-production performance in the conditions prevailing in each region. Such information is provided by PRVT results in the form of the LVR for a given voivodeship.

To test varieties in accordance with the adopted methodology, an appropriate budget needs to be secured. Figure 4 shows PRVT spending for 2010-2020, which amounted to nearly $€ 21$ million. Note that spending is growing, as illustrated by the trend line in the chart below. The average annual expenditure rate of such increase was $5.1 \%$. The operating expenses of the PRVT scheme increased by 64.2\% between 2010 and 2020.

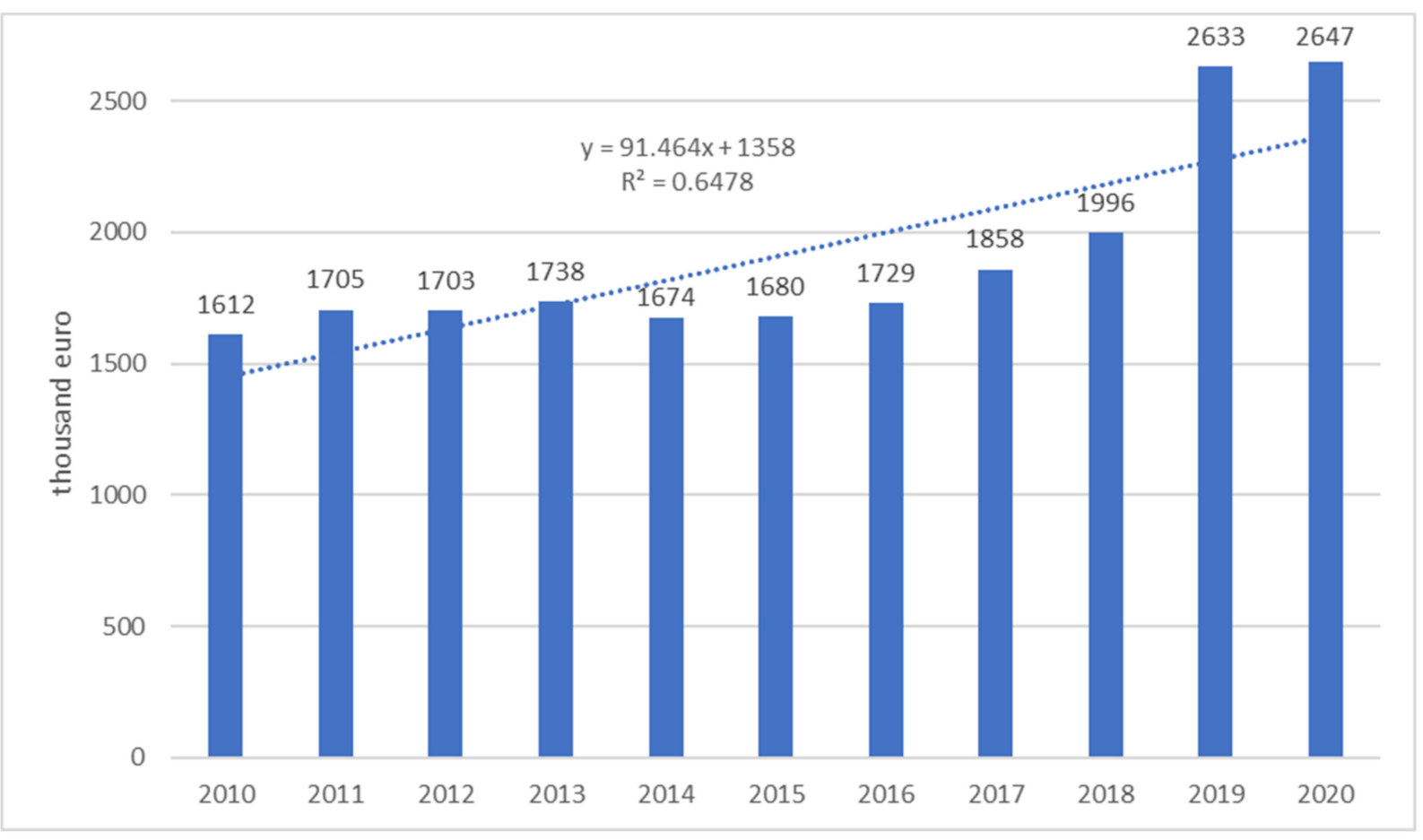

Figure 4. 2010-2020 spending on the PRVT scheme.

PRVT testing is financed by the state and various other sources. As shown in Figure 5, the breakdown of such sources has changed. Currently, the largest share, exceeding 50\%, constitutes funds received by COBORU in the form of a targeted state subsidy. The increase in the share of state funding results from an increase in the number of subsidies granted by the Ministry of Agriculture and Rural Development, which recognizes the importance to agricultural practitioners of access to reliable and objective information on the results of crop tests conducted within the PRVT scheme. In this context, it is worth emphasizing that this way of financing the PRVT program guarantees that the information provided about the tested crop varieties is objective and reliable because it is based on research results coming from PRVT program participants and not on commercial information offered by representatives of seed companies. 


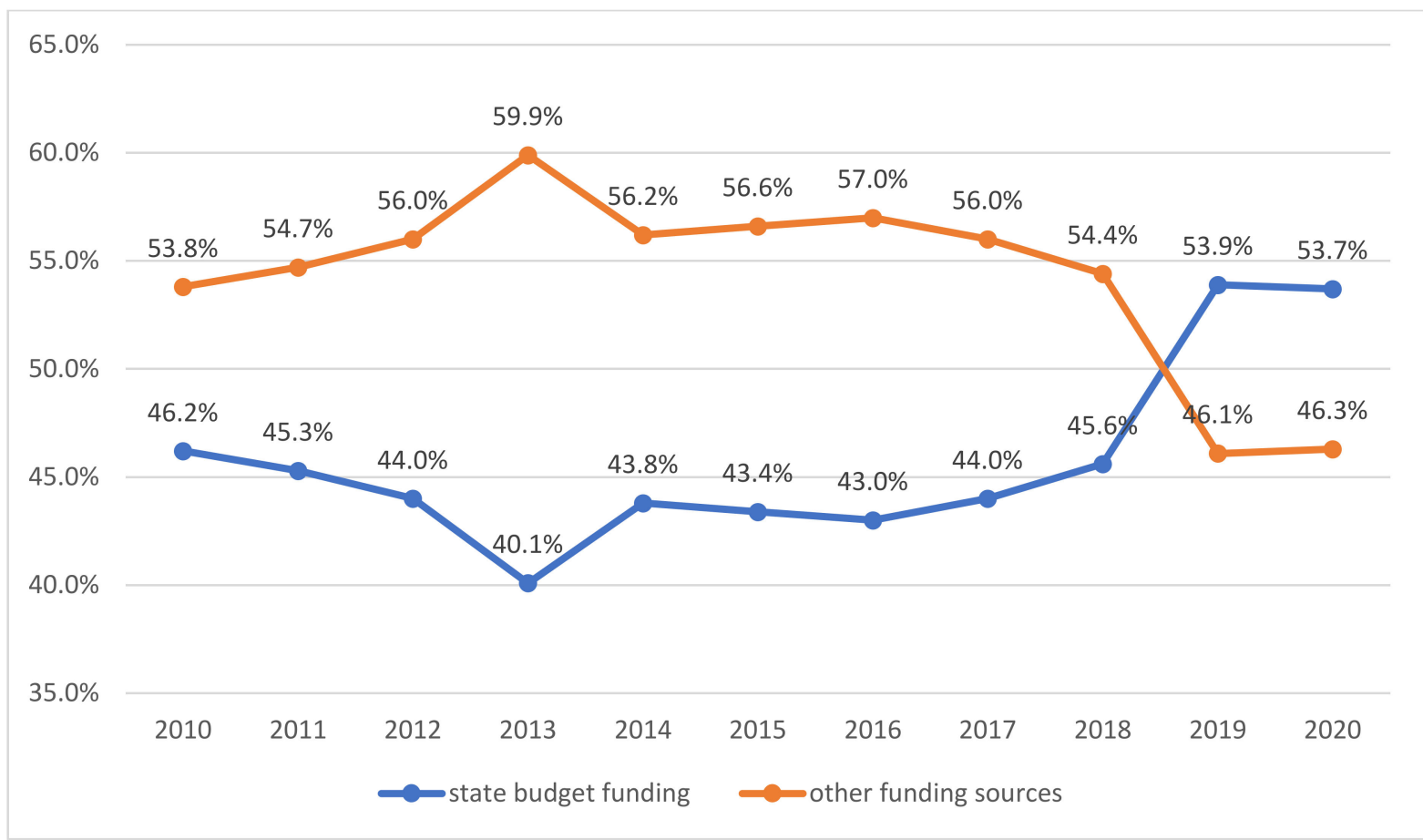

Figure 5. Sources of funding of the PRVT scheme, 2010-2020.

A significant role in financing PRVT research is also played by funds obtained from partners participating the testing system in Poland. Extrabudgetary funds reached their highest proportion in 2013, after breeding companies, especially winter-rape growers, joined the scheme.

Table 2 shows the percentage share of funds obtained from partners participating in PRVT tests. Local and especially regional governments (marshals' offices) contribute a substantial proportion of financing. During the period in question, all of Poland's regional governments joined the PRVT scheme. Total spending by regional governments amounted to close to $€ 3.1$ million. The average annual growth rate in contributions from regional government was $6.7 \%$, totaling a 90.9\% increase between 2010 and 2020 . Funding varied geographically across the regions of Poland, ranging from $€ 3100$ to $€ 41,000$ $(\mathrm{Me} 2010=€ 18,762.00)$ in 2010 and from $€ 4700$ to $€ 31,500(\mathrm{Me} 2020=€ 23,452.00)$ in 2020.

Table 2. Partners who have contributed financially to PRVT testing, 2010-2020.

\begin{tabular}{|c|c|c|c|c|c|c|c|c|c|c|c|}
\hline Partner Type & 2010 & 2011 & 2012 & 2013 & 2014 & $\begin{array}{l}2015 \\
\text { In } \%\end{array}$ & 2016 & 2017 & 2018 & 2019 & 2020 \\
\hline Regional governments (marshals' offices) & 30.5 & 27.6 & 25.0 & 24.2 & 30.6 & 28.4 & 29.8 & 29.2 & 25.9 & 25.6 & 27.4 \\
\hline Agricultural chambers & 1.5 & 1.3 & 1.8 & 2.2 & 2.5 & 2.5 & 2.6 & 2.5 & 2.9 & 2.0 & 2.2 \\
\hline Polish Association of Corn Growers & 4.5 & 4.4 & 3.4 & 3.7 & 4.8 & 5.1 & 4.9 & 5.5 & 5.7 & 5.0 & 4.1 \\
\hline Sugar industry & 2.8 & 2.7 & 2.3 & 2.3 & 2.7 & 2.5 & 2.3 & 2.0 & 2.0 & 1.7 & 1.3 \\
\hline Institute of Soil Science and Plant Cultivation, NRI, Puławy & 6.7 & 5.7 & 1.4 & 0.0 & 0.0 & 0.0 & 0.0 & 0.0 & 0.0 & 0.0 & 0.0 \\
\hline Breeding companies (winter oilseed rape, soybeans) & 0.0 & 0.0 & 0.0 & 8.0 & 8.2 & 7.2 & 6.5 & 6.1 & 6.6 & 5.4 & 5.4 \\
\hline Existing resources of testing organizations & 52.8 & 56.9 & 65.4 & 58.8 & 50.2 & 53.4 & 53.0 & 53.8 & 55.9 & 58.8 & 58.1 \\
\hline Other locally sourced funds & 1.2 & 1.4 & 0.7 & 0.8 & 1.0 & 0.9 & 0.9 & 0.9 & 1.0 & 1.5 & 1.5 \\
\hline
\end{tabular}

On the part of the farming community, the PRVT scheme is supported by agricultural chambers, which contribute financially to PRVT testing to the extent possible. Although their share of such funding is short of substantial, as shown in Table 2, every penny counts, and it is essential for the farming community to show their support.

Substantial support for the PRVT scheme, in particular at the regional level, comes from organizations that test varieties in their own territory and at their own expense, such as breeding and seed organizations, agricultural consultancies, research institutes, and universities. Their share of total non-state funding during the period in question ranged from 
$50.2 \%$ to $65.9 \%$. In some voivodeships, PRVT testing was additionally financed by local enterprises, including fertilizer companies, plant-protection product manufacturers, growers, and even municipal governments, although the share financed by such governments was minor.

The Polish Association of Corn Producers and the sugar industry have also been involved in PRVT testing. Since 2013, testing has additionally been co-financed by breeding companies dealing with winter oilseed rape and soybean.

According to an interview with the PRVT scheme founder, professor Edward S. Gacek, it has been possible to secure funding to pay for all test costs, although it has been a challenge. The fact that the PRVT testing budget has been grown steadily is a testament to the proper functioning of this model, which is held in high regard in both Poland and other EU member states. Professor Edward S. Gacek emphasizes that the PRVT scheme that he created and coordinated is the EU's most effective crop-variety recommendation program. PRVT test results are used to compile lists of varieties recommended for cultivation, broken down by voivodeship. This helps both farmers and other variety users choose varieties best suited to local farming conditions.

\section{Discussion}

The 2018 "Concentration in Seed Markets" report by the OECD indicates that agriculture is currently facing the challenge of increasing productivity while ensuring sustainability and improving crop resilience [45]. One factor that can address these challenges is innovation in agriculture [46]. A vital source of innovation is plant breeding, which is of fundamental importance, particularly in this age in which sustainability has become central to the future of our planet [47]. Without a doubt, the selection of crop varieties adapted to environmental conditions is an integral part of sustainable farming. In this manner, plant breeding and crop-variety testing responds to the fundamental goals and targets of sustainable development, such as hunger reduction, global food security [48], and mitigation of climate change by testing varieties under new and changing climate conditions [49]. The PRVT scheme presented in this paper could be a catalyst for achieving these goals. It is important to note that a variety with high yield potential at one location may not be competitive in another location because of a lack of adaptability to different environments, including weather patterns, soil characteristics, disease pressure, and cropping systems [50]. Undoubtedly, information on crop varieties adapted to local farming conditions is provided by the results of the post-registered measurement surveys made available in the annual lists of varieties recommended (LVR) for regional cultivation.

In retrospect, the precepts and goals adopted by the founders of the post-registration variety-testing scheme have turned out to be well-advised and well ahead of the agricultural policy strategies of the European Union deployed at this time. The agricultural revolution unfolding through the European Green Deal roadmap, the farm-to-fork strategy, and the biodiversity approach promoted by the European Commission relies on a shift away from the use of chemical pesticides and towards genetic resistance that occurs naturally in plants. The European Commission's strategies of 20 May 2020 require that member states reduce the use of pesticides by half by 2030 through the use of biological methods and pathogen-resistant and -tolerant varieties [51]. This makes the use and availability of resistant varieties crucial for crop breeding and cultivation.

In the face of the requirements of integrated control and planned limitations in the use of plant-protection products, the use of resistant varieties, especially the selection of cultivated plant varieties adapted to local farming conditions, is and will be a key element of decision making on farms. The requirements of agricultural product processors and final consumers in access to reliable and proven knowledge about the varieties used should also be taken into account (EU strategy "From the field to the table"). In this context, the information presented herein can facilitate and disseminate access to this type of information aimed at direct agricultural practice. 
These challenges make agriculture an essential factor in ensuring food security, sustainable development, and combating climate change. To meet global human food needs, the world's agricultural system must simultaneously produce more food for a growing population, provide economic opportunities for the rural poor who rely on agriculture for their livelihoods, and reduce environmental impacts [52,53].

The tests described herein aim to determining the suitability of tested crop varieties for specific farming conditions (intensive, low-input, and organic farming) and are perfectly aligned with the previous requirements of integrated pest management that have been in place across the EU since 1 January 2014 (Directive of the Parliament 2009/128/EC of the European Parliament and of the Council of 21 October 2009 establishing a framework for Community action to achieve the sustainable use of pesticides) [54], the Act of 8 March 2013 on plant-protection products [55], Regulation of the Minister of Agriculture and Rural Development of 18 April 2013 on integrated pest management requirements [56], and Regulation of the Minister of Agriculture and Rural Development of 16 December 2010 on integrated production $[57,58]$.

In plant protection, an integrated approach requires that non-chemical methods, especially pathogen-resistant and -tolerant varieties, be used first. With highly variable climate and soil conditions, the regions of Poland vary widely in their capacity to produce high-yield crops. In addition, quality-related traits of harvested crops are also strongly affected by the region in which the crops are cultivated. Agricultural, fruit, vegetable, and ornamental plant varieties, the seeds of which may be produced and traded domestically and throughout the European Union, are included in the National List kept by COBORU.

Since Poland's accession to the EU in 2004, only the seeds admitted to the Common Catalogue of Varieties of Agricultural Plants (CCA) may be traded. All varieties of agricultural, fruit, vegetable, ornamental, and other plants listed in any EU member state are additionally included in the CCA. In 2020, Poland's National List contained 64 varieties of winter wheat. Meanwhile, at the community level in the same year, 1194 varieties were listed in the Common Catalogue, which also made them available and approved for cultivation in Poland.

Poland's systemic transition and, in particular, organizational and ownership changes in the plant-breeding and seed-production sector, as well as Poland's accession to the European Union, created an urgent need for changes in variety testing, leading to the establishment of the PRVT scheme [59,60]. This system filled the information gap that arose as a result of a drastic reduction in the number of field tests conducted in Poland and in the number of registration tests conducted by COBORU in the late 1990s. The variety tests carried out under the PRVT scheme have been tailored to the needs of agricultural practitioners. Such tests were used to create lists of varieties recommended for cultivation in each of the country's regions. The annual recommended lists (LVR) are the main source of information on the cultivation and use value of varieties in each region of Poland. The lists are therefore instrumental in managing the supply of varieties for agriculture [61]. PRVT test results have provided valuable research material for numerous scientific papers on economically significant agricultural plant species, such as sugar beet [62], winter wheat [63-66], winter triticale [67-69], and potato [23,70]. The above-cited works show the versatility of research relying on the tests carried out in the PRVT scheme.

The post-registration variety-test (PRVT) program is a system of permanent and periodic tests of the cultivation and use value of agricultural plant varieties that are of substantial commercial importance and are included in either the National List or the Common Variety Catalogue. The system covers not only variety tests but also variety and agrotechnical tests. First and foremost, however, PRVT is a multistakeholder testing system that brings together cooperating institutions and other organizations with an interest in the development of agriculture at both national and regional levels (local governments, farmers'/growers' associations, government, consultancies, breeding/seed companies, research institutes, trade unions, the processing industry, and other institutions and organizations that foster advances in agriculture). 
Post-registry variety testing is constantly evolving. The ongoing digitization of rural areas, agriculture, and the plant-breeding sector itself has the potential to drive future PRVT development. Even today, varieties are evaluated using state-of-the-art technologies to obtain information on plants. Such technologies range from advanced contact sensors to the Internet of Things (IoT), aerial and satellite imaging, large publicly accessible data sets on agricultural production areas, and AI-enabled cloud computing [71]. The use of digital tools in plant breeding and testing, often called 3D breeding, has the capacity to identify genotypes with enhanced local adaptability for higher production efficiency. However, the digital transformation of variety testing will not continue to move forward unless appropriate policies to promote the digital revolution are formulated and adopted. This very challenge is also now faced by the PRVT scheme.

By engaging in cooperation, participants in the PRVT program will be in a position to provide objective, reliable information on tested crop varieties. In addition, on the macro scale, the PRVT scheme secures the financial benefits that can be derived from selecting the best varieties for cultivation. Major financial benefits may, for instance, be expected in the segment of cereals, the production of which is key to Polish agriculture, also representing a strategic part of the food supply in the EU (Poland is only second to France in terms of area under cereals) [72]. With 7.5 million ha under cereal priced at an average of $€ 17.60$ per $100 \mathrm{~kg}$, a yield increase of, e.g., $10 \mathrm{~kg} / \mathrm{ha}$ or $50 \mathrm{~kg} / \mathrm{ha}$ achieved by using recommended varieties, would translate into financial benefits of $€ 13.2$ million or $€ 66.0$ million, respectively. In fact, the yield increases to be achieved by using cereal varieties recommended on the basis of PRVT tests may even exceed $500 \mathrm{~kg} / \mathrm{ha}$ [42]. In such a case, farmers stand to gain even more from selecting the best varieties.

\section{Conclusions}

Post-registration variety testing is Poland's unique agricultural testing scheme that relies on synergies. We demonstrated that the PRVT scheme was achieved through organizational and economic cooperation among the country's research and testing organizations. While some PRVT tests vary from region to region, others are identical throughout the country. All tests are technically coordinated by COBORU. Based on PRVT test results, lists of varieties recommended for regional cultivation (LVR) are compiled for individual voivodeships.

It is worth highlighting that the benefits of the PRVT scheme result from the fact that:

- $\quad$ advances in biological science are effectively embraced in agriculture;

- $\quad$ objective information about the cultivation and use value of crop varieties, along with information on specific cultivation conditions, is regularly received at both the national regional level in Poland;

- $\quad$ the National List and the CCA help farmers choose varieties with the highest cultivation value that are also best-suited to their local farming conditions.

Based on our research, this article provides an overview of the sources of funding for the post-registration program of cultivar testing. The breakdown of these funding sources shows that test funding has come from varied sources. In the period from 2010 to 2018, the majority of funds came from non-state sources, while from 2019 to 2020, state funds from COBORU constituted the main source of financing.

Statutory partners, particularly regional governments, are provide significant funds to the PRVT scheme. However, both in absolute terms and per 1 ha of agricultural land, funding from regional governments has differed from region to region.

Spending on testing in the PRVT scheme is growing steadily, as confirmed by our research. During the period in question, nearly $€ 21$ million was appropriated to that aim. The average annual spending increase was $5.1 \%$.

With more money secured for PRVT tests, it is possible to increase the number of crop species covered by post-registration variety testing every year and, consequently, provide objective cultivation test results to farmers. 
This paper shows that the PRVT scheme is focused on testing plant species intended for conventional cultivation. In our view, the PRVT scheme should soon be extended to varieties dedicated for use in organic farming, which are desirable, owing to the potential of such farming to help make agriculture sustainable.

Our research is not devoid of limitations, which need to be addressed going forward. The key drawback is that our analysis relies on secondary materials in the form of reports on PRVT rollout. Notably, however, the empirical material we were able to collect by this method is highly reliable.

To the best of our knowledge, no literature reviews are available that explore the commercial value of post-registration variety testing. Our research fills this gap. Future studies should consider the way in which agricultural producers can benefit financially from use of the LVR for cultivation in specific regions. The PRVT testing program and the system of disseminating its test results through LVR should be used to provide valuable inspiration and an example to be followed in other countries around the world.

Breeding programs experience continuous changes caused by, among other factors, climate change and the evolving threats of disease and pests. In view of the constant changes in access to registered varieties, it is necessary to emphasize the urgent need to expand the analyses and research carried out under the PRVT system and to further promote and disseminate the results obtained from this type of research, both in dissemination reports distributed among agricultural practitioners and in scientific journals.

In conclusion, the presented results are certainly not exhaustive, but they may serve as useful source of knowledge on the functioning and sources of financing of the PRVT program. The presented framework of PRVT financing could be a valuable source of information for the implementation of such a system it in other countries; therefore, our paper fills an existing gap in the specialized scientific literature.

Author Contributions: Conceptualization, G.N., A.T. and J.U.; data curation, G.N., A.T., M.P., T.W. and J.U.; methodology, J.U.; software, G.N., J.U. and A.T.; validation, G.N., A.T., M.P., T.W. and J.U.; formal analysis, G.N., A.T., M.P., T.W. and J.U.; investigation, G.N., A.T. and J.U.; resources, A.T. and J.U.; writing-original draft preparation, G.N., A.T., M.P., T.W. and J.U.; writing-review and editing, G.N., A.T. and J.U.; visualization, J.U.; supervision, G.N. and J.U.; project administration, G.N. and J.U. All authors have read and agreed to the published version of the manuscript.

Funding: This research received no external funding.

Institutional Review Board Statement: Not applicable.

Informed Consent Statement: Not applicable.

Data Availability Statement: Not applicable.

Acknowledgments: The authors would like to thank Edward S. Gacek for valuable comments and leads provided during the conducted study.

Conflicts of Interest: The authors declare no conflict of interest.

\section{References}

1. Willer, H.; Lernoud, J. (Eds.) The World of Organic Agriculture. Statistics and Emerging Trends 2019, 20th ed.; Research Institute of Organic Agriculture FiBL and IFOAM Organics International, Frick and Bonn: Bonn, Germany, 2019.

2. Murphy, K.M.; Campbell, K.G.; Lyon, S.R.; Jones, S.S. Evidence of varietal adaptation to organic farming systems. Field Crops Res. 2007, 102, 172-177. [CrossRef]

3. Kovacs, T.; Mariegaard Pedersen, T. Overview on the Current Organizational Models for Cultivar Testing for Organic Agriculture over Some EU Countries; Report for LIVESEED project-Boosting organic seed and plant breeding across Europe 2017-2021; 2019. Available online: https://www.liveseed.eu/wp-content/uploads/2020/11/LIVESEED-D2.1_Overview-of-the-organisationalmodels-of-cultivar-trials-for-organic-agriculture_corrected-version_TMP.pdf (accessed on 30 August 2021).

4. Research Centre for Cultivar Testing (COBORU). Available online: http:/ / www.coboru.gov.pl (accessed on 1 October 2021).

5. Derejko, A. Response of Winter wheat cultivars to the environment and crop management in post-registration multi-environment trials (PDO). Maz. Stud. Reg. 2016, 18, 181-196. [CrossRef] 
6. Coomes, O.T.; McGuire, S.J.; Garine, E.; Caillon, S.; McKey, D.; Demeulenaere, E.; Jarvis, D.; Aistara, G.; Barnaud, A.; Clouvel, P.; et al. Farmer seed networks make a limited contribution to agriculture? Four common misconceptions. Food Policy 2015, 56, 41-50. [CrossRef]

7. Science \& Advice for Scottish Agriculture (SASA). Available online: https:/ / www.sasa.gov.uk/ (accessed on 1 October 2021).

8. Provisions, G. Act of 26 June 2003 on the Legal Protection of Plant Varieties as Last Amended in 2011. Available online: https:/ / wipolex-res.wipo.int/edocs/lexdocs/laws/en/pl/pl053en.pdf (accessed on 1 October 2021).

9. COUNCIL REGULATION (EC) NO 2100/94 of 27 July 1994 on community plant variety rights. 1994. Available online: https:/ / cpvo.europa.eu/sites/default/files/documents/lex/394R2100/EN394R2100.pdf (accessed on 4 October 2021).

10. Commission Regulation (EC) NO 1768/95 of 24 July 1995 Laying down Implementing Rules as Regards the Agricultural Exemption Provided for in Article 14 Paragraph 3 of Council Regulation (EC) No 2100/94 on Community Plant Variety Rights Plants. Available online: https:/ / eur-lex.europa.eu/legal-content/PL/TXT/PDF/?uri=CELEX:31995R1768\&from=EN (accessed on 1 October 2021).

11. Commission Regulation (EC) NO 2605/98 of 3 December 1998 Amending Regulation (EC) No 1768/95 Laying down Implementing Rules as Regards the the Agricultural Exemption Provided for in Article 14(3) of Council Regulation (EC) No $2100 / 94$ on Community Plant va. Available online: https:/ / eur-lex.europa.eu/legal-content/PL/TXT/PDF/?uri=CELEX:31998R2605\& from $=\mathrm{EN}$ (accessed on 1 October 2021).

12. Konopka, I.; Fornal, L.; Abramczyk, D.; Rothkaehl, J.; Rotkiewicz, D. Statistical evaluation of different technological and rheological tests of Polish wheat varieties for bread volume prediction. Int. J. Food Sci. Technol. 2004, 39, 11-20. [CrossRef]

13. Law of 9 November 2012 on Seeds. Available online: https:/ /isap.sejm.gov.pl/isap.nsf/download.xsp/WDU20120001512/U/D2 0121512Lj.pdf (accessed on 1 October 2021).

14. Wicki, L. System of collection and distribution knowledge about plant varieties in Poland. In Knowledge Management in Agribusiness in Conditions of Polish Membership in the European Union; Sci. Pap 35; SGGW: Warszawa, Poland, 2005; pp. 395-404.

15. Wicki, L. Lists of recommended varieties influence on polish market of winter wheat seed. Ann. Pol. Assoc. Agric. Agribus. Econ. 2005, 7, 235-2391.

16. Announcement by the Minister of Agriculture and Rural Development of 19 March 2001 on the Publication of the Consolidated Text of the Seed Production Act. Available online: http:/ / isap.sejm.gov.pl/isap.nsf/download.xsp/WDU20010530563/T/D200 10563L.pdf (accessed on 1 October 2021).

17. Order No 11 of the Minister for Agriculture and Rural Development of 11 June 2002 on Granting Statutes to the Central Centre for Testing Plant Varieties of Crops. Available online: https://sip.lex.pl/akty-prawne/dzienniki-resortowe/nadanie-statutucentralnemu-osrodkowi-badania-odmian-roslin-uprawnych-33743762 (accessed on 1 October 2021).

18. Notice of the Minister for Agriculture and Rural Development of 27 May 2021 on the Publication of the Consolidated Text of the Regulation of the Minister of Agriculture and Rural Development on Granting Statutes to the Research Centre for Cultivar Testing. Available online: https:/ /dziennikustaw.gov.pl/D2021000102401.pdf (accessed on 1 October 2021).

19. Gacek, E.; Behnke, M. Practical application of the biological progress in agriculture in conditions of the market economy. Biul. Plant Breed. Aclim. Inst. 2006, 240-241, 83-89.

20. Studnicki, M.; Wijata, M.; Sobczyński, G.; Samborski, S.; Rozbicki, J. Assessing grain yield and quality traits stability of spring wheat cultivars at different crop management levels. Cereal Res. Commun. 2018, 46, 180-190. [CrossRef]

21. Studnicki, M.; Wijata, M.; Sobczyński, G.; Samborski, S.; Gozdowski, D.; Rozbicki, J. Corrigendum to "Effect of genotype, environment and crop management on yield and quality traits in spring wheat". J. Cereal Sci. 2017, 75, 332. [CrossRef]

22. Paderewski, J.; Gauch, H.G.; Mądry, W.; Drzazga, T.; Rodrigues, P.C. Yield Response of Winter Wheat to Agro-Ecological Conditions Using Additive Main Effects and Multiplicative Interaction and Cluster Analysis. Crop Sci. 2011, 51, 969-980. [CrossRef]

23. Piekutowska, M.; Niedbała, G.; Piskier, T.; Lenartowicz, T.; Pilarski, K.; Wojciechowski, T.; Pilarska, A.A.; Czechowska-Kosacka, A. The Application of Multiple Linear Regression and Artificial Neural Network Models for Yield Prediction of Very Early Potato Cultivars before Harvest. Agronomy 2021, 11, 885. [CrossRef]

24. Smith, A.B.; Ganesalingam, A.; Kuchel, H.; Cullis, B.R. Factor analytic mixed models for the provision of grower information from national crop variety testing programs. Theor. Appl. Genet. 2015, 128, 55-72. [CrossRef]

25. Vartanian, T.P. Secondary Data Analysis; Oxford University Press: New York, NY, USA, 2010; ISBN 9780195388817.

26. Walliman, N. Social Research Methods: The Essentials, 2nd ed.; SAGE Publications Ltd.: Los Angeles, CA, USA, 2015; ISBN 9781473916203.

27. Davis, J.; Mengersen, K.; Bennett, S.; Mazerolle, L. Viewing systematic reviews and meta-analysis in social research through different lenses. SpringerPlus 2014, 3, 511. [CrossRef]

28. Snyder, H. Literature review as a research methodology: An overview and guidelines. J. Bus. Res. 2019, 104, 333-339. [CrossRef]

29. Reimer, B.; Brett, M. Scientific Knowledge and Rural Policy: A Long-distant Relationship. Sociol. Ruralis 2013, 53, 272-290. [CrossRef]

30. Wartecka-Ważyńska, A.; Jęczmyk, A.; Jalinik, M.; Sikora, J.; Łuniewski, S.; Uglis, J. The Context of Sustainable Development: Funding Society's Nature and Forest Education through Promotional Forest Complexes in Poland in 2012-2016. Sustainability 2019, 11, 4058. [CrossRef]

31. Frankfort-Nachmias, C.; Nachmias, D. Research Methods in the Social Sciences; St. Martin's Press: New York, NY, USA, 1996; ISBN 0312101597. 
32. COBORU. Sprawozdanie z Realizacji Programu Porejestrowego Doświadczalnictwa Odmianowego w Roku 2010; COBO 13/2011; Centralny Ośrodek Badania Odmian Roślin Uprawnych: Słupia Wielka, Poland, 2011.

33. COBORU. Sprawozdanie z Realizacji Programu Porejestrowego Doświadczalnictwa Odmianowego w Roku 2011; COBO 19/2012; Centralny Ośrodek Badania Odmian Roślin Uprawnych: Słupia Wielka, Poland, 2012.

34. COBORU. Sprawozdanie z Realizacji Programu Porejestrowego Doświadczalnictwa Odmianowego w Roku 2012; COBO 27/2013; Centralny Ośrodek Badania Odmian Roślin Uprawnych: Słupia Wielka, Poland, 2013.

35. COBORU. Sprawozdanie z Realizacji Programu Porejestrowego Doświadczalnictwa Odmianowego w Roku 2013; COBO 17/2014; Centralny Ośrodek Badania Odmian Roślin Uprawnych: Słupia Wielka, Poland, 2014.

36. COBORU. Sprawozdanie z Realizacji Programu Porejestrowego Doświadczalnictwa Odmianowego w Roku 2014; COBO 11/2015; Centralny Ośrodek Badania Odmian Roślin Uprawnych: Słupia Wielka, Poland, 2015.

37. COBORU. Sprawozdanie z Realizacji Programu Porejestrowego Doświadczalnictwa Odmianowego w Roku 2015; COBO 10/2016; Centralny Ośrodek Badania Odmian Roślin Uprawnych: Słupia Wielka, Poland, 2016.

38. COBORU. Sprawozdanie z Realizacji Programu Porejestrowego Doświadczalnictwa Odmianowego w Roku 2016; COBO 15/2017; Centralny Ośrodek Badania Odmian Roślin Uprawnych: Słupia Wielka, Poland, 2017.

39. COBORU. Sprawozdanie z Realizacji Programu Porejestrowego Doświadczalnictwa Odmianowego w Roku 2017; COBO 16/2018; Centralny Ośrodek Badania Odmian Roślin Uprawnych: Słupia Wielka, Poland, 2018.

40. COBORU Sprawozdanie z Realizacji Programu Porejestrowego Doświadczalnictwa Odmianowego w Roku 2018; COBO 12/2019; Centralny Ośrodek Badania Odmian Roślin Uprawnych: Słupia Wielka, Poland, 2019.

41. COBORU. Sprawozdanie z Realizacji Programu Porejestrowego Doświadczalnictwa Odmianowego w Roku 2019; COBO 14/2020; Centralny Ośrodek Badania Odmian Roślin Uprawnych: Słupia Wielka, Poland, 2020.

42. COBORU. Sprawozdanie z Realizacji Programu Porejestrowego Doświadczalnictwa Odmianowego w Roku 2020; COBO 34/2021; Centralny Ośrodek Badania Odmian Roślin Uprawnych: Słupia Wielka, Poland, 2021.

43. Punch, K. Introduction to Social Research Quantitative and Qualitative Approaches, 2nd ed.; SAGE Publications Ltd.: London, UK, 2005; ISBN 0761944168.

44. Listy Odmian Zalecanych do Uprawy na Obszarze Województwa. Available online: https://coboru.gov.pl/PDO/rekomendacja. aspx (accessed on 1 October 2021).

45. OECD. Concentration in Seed Markets: Potential Effects and Policy Responses; OECD Publishing: Paris, France, 2018; ISBN 9789264308350. [CrossRef]

46. Kock, M.A. Open Intellectual Property Models for Plant Innovations in the Context of New Breeding Technologies. Agronomy 2021, 11, 1218. [CrossRef]

47. Bostyn, S.J.R. Towards a Fair Scope of Protection for Plant Breeders' Rights in an Era of New Breeding Techniques: Proposals for a Modernization of the Essentially Derived Variety Concept. Agronomy 2021, 11, 1511. [CrossRef]

48. Lenaerts, B.; Collard, B.C.Y.; Demont, M. Review: Improving global food security through accelerated plant breeding. Plant Sci. 2019, 287, 110207. [CrossRef]

49. Braun, H.J.; Atlin, G.; Payne, T. Multi-location testing as a tool to identify plant response to global climate change. In Climate Change and Crop Production; CABI: Wallingford, CT, USA, 2010; pp. 115-138.

50. Moseley, D.; Harrison, S.; Padgett, B.; Price, T.; Harrell, D.; Gravois, K.; La Bonte, D.; Foster, M. Variety Testing: A Critical Component for Sustainable Production Systems. Available online: https://www.lsuagcenter.com/profiles/lbenedict/articles/ page1616509258050 (accessed on 27 December 2021).

51. 2050 Long-Term Strategy. Available online: https:/ / ec.europa.eu/clima/eu-action/climate-strategies-targets/2050-long-termstrategy_en (accessed on 1 October 2021).

52. Searchinger, T.; Hanson, C.; Ranganathan, J.; Lipinski, B.; Waite, R.; Winterbottom, R.; Dinshaw, A.; Heimlich, R. Creating a Sustainable Food Future: Interim Findings. A Menu of Solutions to Sustainably Feed More than 9 Billion People by 2050; World Resources Institute (WRI): Washington, DC, USA, 2013; ISBN 978-1-56973-817-7.

53. Capone, R.; Bilali, H.E.; Debs, P.; Cardone, G.; Driouech, N. Food System Sustainability and Food Security: Connecting the Dots. J. Food Secur. 2014, 2, 13-22. [CrossRef]

54. Directive 2009/128/EC of the European Parliament and of the Council of 21 October 2009 Establishing a Framework for Community Action to Achieve the Sustainable Use of Pesticides. Available online: https://eur-lex.europa.eu/eli/dir/2009/128 / oj (accessed on 1 October 2021).

55. Ustawa o Środkach Ochrony Roślin. Dz. U. z 2020 r. poz. 2097. Available online: https://isap.sejm.gov.pl/isap.nsf/DocDetails. xsp?id=WDU20200002097 (accessed on 1 October 2021).

56. Rozporządzenie Ministra Rolnictwa i Rozwoju Wsi w Sprawie Wymagań Integrowanej Ochrony Roślin. Dz. U. z 2013 r. poz. 505. Available online: http:/ / isap.sejm.gov.pl/isap.nsf/DocDetails.xsp?id=WDU20130000505 (accessed on 1 October 2021).

57. Rozporządzenie Ministra Rolnictwa i Rozwoju Wsi z Dnia 16 Grudnia 2010 r. w Sprawie Integrowanej Produkcji. Dz. U. nr 256, poz. 1722. Available online: http://isap.sejm.gov.pl/isap.nsf/DocDetails.xsp?id=WDU20102561722 (accessed on 1 October 2021).

58. Integrowana Ochrona Roślin. Available online: https://www.gov.pl/web/rolnictwo/integrowana-ochrona-roslin (accessed on 1 October 2021).

59. Gacek, E. Program porejestrowego doświadczalnictwa odmianowego w Polsce. Hod. Roślin i Nasienn 1998, 3, 32-34. 
60. Gacek, E.; Behnke, M. Wdrażanie postępu biologicznego do praktyki rolniczej w warunkach gospodarki rynkowej. Biul. IHAR 2006, 240, 83-90.

61. Porejestrowe Doświadczalnictwo Odmianowe (PDO). Available online: www.coboru.gov.pl/pdo/pdo (accessed on 1 October 2021).

62. Studnicki, M.; Lenartowicz, T.; Noras, K.; Wójcik-Gront, E.; Wyszyński, Z. Assessment of Stability and Adaptation Patterns of White Sugar Yield from Sugar Beet Cultivars in Temperate Climate Environments. Agronomy 2019, 9, 405. [CrossRef]

63. Studnicki, M.; Derejko, A.; Wójcik-Gront, E.; Kosma, M. Adaptation patterns of winter wheat cultivars in agro-ecological regions. Sci. Agric. 2019, 76, 148-156. [CrossRef]

64. Iwańska, M.; Paderewski, J.; Stępień, M.; Rodrigues, P. Adaptation of Winter Wheat Cultivars to Different Environments: A Case Study in Poland. Agronomy 2020, 10, 632. [CrossRef]

65. Rozbicki, J.; Ceglińska, A.; Gozdowski, D.; Jakubczak, M.; Cacak-Pietrzak, G.; Mądry, W.; Golba, J.; Piechociński, M.; Sobczyński, G.; Studnicki, M.; et al. Influence of the cultivar, environment and management on the grain yield and bread-making quality in winter wheat. J. Cereal Sci. 2015, 61, 126-132. [CrossRef]

66. Mądry, W.; Derejko, A.; Studnicki, M.; Paderewski, J.; Gacek, E. Response of winter wheat cultivars to crop management and environment in post-registration trials. Czech J. Genet. Plant Breed 2017, 53, 76-82. [CrossRef]

67. Tratwal, A.; Roik, K.; Kardasz, P.; Bocianowski, J. Plonowanie wybranych odmian pszenżyta ozimego w ramach Porejestrowego Doświadczalnictwa Odmianowego. Zagadnienia Doradz. Rol. 2018, 4, 73-88.

68. Tratwal, A.; Bocianowski, J.; Cyplik, A. The impact of the level of agricultural technology on winter triticale (Triticosecale Wittm. ex A. Camus) diseases studied as a part of post-registration variety experimentation. Prog. Plant Prot. 2019, 59, 237-243. [CrossRef]

69. Derejko, A.; Studnicki, M.; Wójcik-Gront, E.; Gacek, E. Adaptive Grain Yield Patterns of Triticale (×Triticosecale Wittmack) Cultivars in Six Regions of Poland. Agronomy 2020, 10, 415. [CrossRef]

70. Lenartowicz, T.; Piepho, H.-P.; Przystalski, M. Stability Analysis of Tuber Yield and Starch Yield in Mid-Late and Late Maturing Starch Cultivars of Potato (Solanum tuberosum). Potato Res. 2020, 63, 179-197. [CrossRef]

71. De Sousa, K.; van Etten, J.; Poland, J.; Fadda, C.; Jannink, J.-L.; Kidane, Y.G.; Lakew, B.F.; Mengistu, D.K.; Pè, M.E.; Solberg, S.Ø.; et al. Data-driven decentralized breeding increases prediction accuracy in a challenging crop production environment. Commun. Biol. 2021, 4, 944. [CrossRef]

72. Rynek zbóż w Polsce. Krajowy Ośrodek Wparcia Rolnictwa, KOWR 2020. Available online: https:/ / www.kowr.gov.pl/uploads/ pliki/wydawnictwa/2020/Broszura_Rynek_zboz_w_Polsce_12.2020.pdf (accessed on 1 October 2021). 